\title{
Time to peak postprandial glucose levels in childhood-onset diabetic patients analyzed with a continuous glucose monitoring system
}

\author{
Junichi Suzuki, Remi Kuwabara, Masako Habu, Misako Okuno, Ayako Yoshida, Tatsuhiko Urakami \\ From 7th APPES Biennial Scientific Meeting \\ Nusa Dua, Bali. 14-17 November 2012
}

The risks of complications due to chronic diabetes are indicated by an increase in average blood glucose levels and the range of blood glucose level fluctuation. Postprandial hyperglycemia should be the target of glycemic control in clinical practice. There are few studies on the time to peak postprandial glucose levels in children. Therefore, we investigated the time to peak in childhoodonset diabetic patients using a continuous glucose monitor system (CGMS).

Twenty-seven patients with childhood-onset diabetes were included (male to female ratio, 9:18): 20 had type 1 diabetes, 3 had type 2 diabetes, and 4 had other types of diabetes. All patients underwent CGM on admission using the CGMS; their blood glucose levels were monitored up to $3 \mathrm{~h}$ after each meal. The time to peak postprandial blood glucose levels was retrospectively determined.

The CGMS recorded the postprandial glucose levels 266 times. Average peak time of postprandial blood glucose and average blood glucose excursion were $96.3 \pm$ $56.7 \mathrm{~min}$ and $86.5 \pm 56.7 \mathrm{mg} / \mathrm{dL}$, respectively. The average peak time and average blood glucose excursion were as follows: type 1 diabetes, $91.2 \pm 56 \mathrm{~min}$ and $80.0 \pm$ $62.3 \mathrm{mg} / \mathrm{dL}$; type 2 diabetes, $92.7 \pm 42.6 \mathrm{~min}$ and $105.8 \pm$ $52.2 \mathrm{mg} / \mathrm{dL}$; other types of diabetes, $112.1 \pm 50.7 \mathrm{~min}$ and $82.8 \pm 42.7 \mathrm{mg} / \mathrm{dL}$. The average peak time and blood glucose excursion for meals were as follows: breakfast, 108.4 $\pm 53.7 \mathrm{~min}$ and $92.6 \pm 60.6 \mathrm{mg} / \mathrm{dL}$; lunch, $93.2 \pm 51.8 \mathrm{~min}$ and $83.4 \pm 48.6 \mathrm{mg} / \mathrm{dL}$; and dinner, $88.3 \pm 54.0 \mathrm{~min}$ and $83.9 \pm 60.0 \mathrm{mg} / \mathrm{dL}$. There was no correlation between time to peak postprandial blood glucose and HbA1c levels.

The average time to peak postprandial blood glucose levels was approximately $90 \mathrm{~min}$ in both type 1 and 2

Department of Pediatrics and Child Health, Nihon University School of Medicine, Tokyo, Japan

(c) 2013 Suzuki et al; licensee BioMed Central Ltd. This is an Open Access article distributed under the terms of the Creative Commons Attribution License (http://creativecommons.org/licenses/by/2.0), which permits unrestricted use, distribution, and reproduction in any medium, provided the original work is properly cited. diabetes patients. The time to peak postprandial blood glucose levels reported here was delayed as compared to other studies on Japanese healthy adults with childhoodonset diabetes. The time to peak postprandial blood glucose levels in childhood-onset diabetic patients was approximately $90 \mathrm{~min}$. As an indicator of glycemic control in childhood-onset diabetic patients, the CGMS was considered useful for determining the postprandial blood glucose levels in clinical practice.

Published: 3 October 2013

doi:10.1186/1687-9856-2013-S1-P27

Cite this article as: Suzuki et al:: Time to peak postprandial glucose levels in childhood-onset diabetic patients analyzed with a continuous glucose monitoring system. International Journal of Pediatric Endocrinology 2013 2013(Suppl 1):P27.

Submit your next manuscript to BioMed Central and take full advantage of:

- Convenient online submission

- Thorough peer review

- No space constraints or color figure charges

- Immediate publication on acceptance

- Inclusion in PubMed, CAS, Scopus and Google Scholar

- Research which is freely available for redistribution

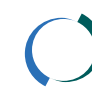

